\title{
MODEL SPASIAL STATISTIK KEPEMILIKAN SEPEDA MOTOR DI KECAMATAN BANYUMANIK, KOTA SEMARANG
}

\author{
S.Y.Ardiansyah ${ }^{\mathrm{a}}$, A.R.Rakhmatullah ${ }^{\mathrm{b}}$ \\ a Universitas Diponegoro, Indonesia, email: shepta yudha@yahoo.co.id \\ ${ }^{b}$ Universitas Diponegoro, Indonesia, email: anita.ratnasari.r@gmail.com
}

\begin{abstract}
Article Info;
Abstract: Semarang is a fast forward and fast growing city viewed from its economic growth.

Received:

5 September 2014

However, the increased population along by increased activity gives a new difficulty, that is congestion. The existence of urbanization encourages people tend to prefer a suburban area to the center of the city. With the growing movement of transportation activity, it has pushed

in revised form:

15 September 2014 the level of ownership of private vehicles, especially motorcycles in the suburbs. Banyumanik Sub-district as a suburb of the Semarang City is functioned as settlements development direction. Banyumanik Sub-district is the highest number of motorcycle ownership in

Accepted:

17 September 2014 Semarang sub urban with the amount of 20.428 units. For understanding the motorcycle ownership concentration, it is required the study of distribution and spatial aspects, so that it can be seen spreading evenly or not. The method used in this research is quantitative

Available Online:

1 October 2014

Keywords:

Banyumanik

Subdistrict,

Motorcycle

Ownership, Spatial

Patterns, GIS descriptive and spatial modeling approach named Spatial Statistics Analysis. The analysis methods used in this study is using the method of analysis Descriptive Statistics. The analytical tool uses a GIS (Geographic Information System). According to the research results, it is revealed that the movement system of the motorcycle user community in Banyumanik Subdistrict reaches until 37\% toward the center of the city, 58\% Banyumanik stir around the area, and a 5\% move toward Semarang regency. As a results of the analysis of spatial patterns, it is showed that the distribution of the motorcycles ownership forms a cluster pattern with a high concentration level (High Cluster). The highest concentrations of motorcycle ownership exist in the surrounding area Perumnas Banyumanik, while the lowest ownership concentration is in the region such as the Bukitsari Residence, and Graha Estetika Residence.
\end{abstract}

Info Artikel;

Diterima:

5 September 2014

Hasil Revisi :

15 September 2014

Disetujui:

17 September 2014

Publikasi On-Line:

1 Oktober 2014

\section{Kata kunci:}

Kecamatan

Banyumanik,

Kepemilikan Sepeda

Motor, Pola Spasial,

GIS
Abstrak: Kota Semarang merupakan kota cepat maju dan cepat tumbuh dilihat dari pertumbuhan ekonominya, namun demikian peningkatan jumlah penduduk yang disertai dengan meningkatnya aktivitas memberikan permasalahan baru yakni kemacetan. Adanya urbanisasi mendorong masyarakat cenderung lebih memilih kawasan pinggiran kota untuk tinggal. Dengan meningkatnya pergerakan aktivitas terhadap transportasi telah mendorong tingkat kepemilikan kendaraan pribadi terutama sepeda motor di kawasan pinggiran. Kecamatan Banyumanik sebagai kawasan pinggiran Kota Semarang difungsikan sebagai arahan pengembangan kawasan permukiman. Kecamatan Banyumanik merupakan kecamatan yang memiliki jumlah kepemilikan kendaraan terbanyak di kawasan pinggiran Semarang dengan jumlah sebesar 20.428 unit. Untuk memahami konsentrasi kepemilikan sepeda motor diperlukan penelitian dari distribusi dan dari aspek spasialnya, agar dapat dilihat persebarannya merata atau tidak. Metode yang dipakai dalam penelitian ini adalah deskriptif kuantiatif dan pendekatan pemodelan spasial yakni Spatial Statistic Analysis. Metode Analisis yang digunakan dalam penelitian ini menggunakan metode analisis Statistik Deskriptif. Alat analisis yang digunakan menggunakan bantuan GIS (Geographic Information System). Berdasarkan hasil penelitian diketahui bahwa pola pergerakan masyarakat pengguna sepeda motor di Kecamatan Banyumanik 37\% menuju pusat Kota Semarang, 58\% begerak di sekitar kawasan Banyumanik, dan 5\% bergerak menuju ke Kabupaten Semarang. Sedangkan untuk hasil analisis pola spasial, didapatkan hasil bahwa distribusi atas kepemilikan sepeda motor membentuk sebuah pola klaster dengan tingkat konsentrasi tinggi (High Cluster). Konsentrasi kepemilikan sepeda motor tertinggi berada di sekitar kawasan Perumnas Banyumanik, sedangkan konsentrasi kepemilikan terendah berada di wilayah seperti Perumahan Bukitsari dan Graha Estetika. 


\section{PENDAHULUAN}

Kota Semarang sebagai salah satu kota besar di Indonesia dan sebagai Ibu Kota Provinsi Jawa Tengah, setiap harinya terdapat 852.496 kendaraan yang melintas lalu lalang di jalan raya. Tingginya angka kepemilikan kendaraan pribadi membuat kota Semarang kian hari kemacetan semakin bertambah. Jumlah sepeda motor di tiap kecamatan berbeda-beda dan jika ditelusuri akan terdapat karaketristik yang menarik untuk diteliti. Dengan karakteristik yang berbeda tersebut peneliti berusaha mengidentifikasi pola spasial yang terbentuk dari kepemilikan kendaraan sepeda motor di kawasan pinggiran Kota Semarang. Seiring bertambahnya penduduk di pusat kota, penduduk akan lebih memilih tempat tinggal yang lebih tenang yakni di kawasan pinggiran.

Bertambahnya jumlah kepemilikan sepeda motor dapat menyebabkan permasalahan turunan dalam bidang transportasi. Fenomena yang menarik tentang keterkaitan antara perilaku perjalanan dan pola spasial adalah dalam hal bangkitan perjalanan. Jika ditinjau dari segi spasialnya, maka akan membentuk distribusi persebaran, bangkitan dan pola tersendiri dari kepemilikan sepeda motor yang berbeda-beda di pusat kota ataupun di pinggiran Kota Semarang. Tujuan dari penelitian ini adalah untuk mengidentifikasi distribusi dan pola spasial yang terbentuk berdasarkan kepemilikan sepeda motor di pinggiran Kota Semarang yakni Kecamatan Banyumanik. Dengan penggunaan pola spasial diharapkan masyarakat dapat lebih mengerti bagaumanakah kepemilikan kendaraan bermotor terkonsentrasi terutama di kawasan pinggiran kota Semarang. Pertimbangan pemilihan wilayah studi di Kecamatan Banyumanik adalah karena kepemilikan sepeda motor di Banyumanik merupakan yang tertinggi jika dibandingkan dengan kecamatan pinggiran lain yang jauh dari pusat kota. Perkembangan kawasan Banyumanik yang pesat yakni banyaknya perumahan-perumahan baru juga ikut bertambahnya jumlah penduduk yang tinggal di kecamatan ini dan menggunakan sepeda motor.

\section{DATA DAN METODE}

\subsection{Travel Behavior}

Terdapat indikator statistik dalam travel behavior yakni:

- Travel Rate (Tingkat Perjalanan)

Merupakan frekuensi perjalanan rata-rata penduduk setiap hari utuk melakukan aktivitasnya. Tingkat perjalanan dipengaruhi oleh gender seseorang, untuk wanita biasanya dalam melakukan aktivitasnya cenderung lebih sedikit daripada pria. Selain itu faktor usia juga mempengaruhi tingkat perjalanan masyarakat. Masyarakat yang berumur $>60$ tahun cenderung relatif kecil pergerakannya karena dipengaruhi oleh karakteristik fisiknya.

- Travel Time Consumption

Merupakan waktu perjalanan yang dihabiskan untuk menyelesaikan perjalanan mereka, atau yang biasa disebut dengan waktu tempeh perjalanan.

- Travel Purpose

Tujuan perjalanan tidak hanya berbasis kepada permintaan perjalanan, tetapi menunjukkan tentang kegiatan yang akan dilakukan setelah sampai tujuan. Aktivitas yang dilakukan dapat berupa bekerja, belanja, sekolah, dll.

- Travel Mode

Moda perjalanan merupakan alat transportasi yang digunakan untuk melakukan aktivitasnya. Moda dapat berupa kendaraan bermotor seperti bus, sepeda motor dan mobil atau juga bersepeda atau berjalan kaki.

\subsection{Pola Guna Lahan}

Pola guna lahan dalam bangkitan perjalanan dan awal pergerakan masyarakat berasal dari perumahan. Menurut (Suparno \& Marlina, 2006) dalam perumahan, jenis rumah dikategorikan berdasarkan tipe rumah. Jenis rumah tersebut terdiri atas:

a. Rumah Sederhana

Rumah Sederhana merupakan rumah bertipe kecil, yang mempunyai keterbatasan dalam perencanaan ruangnya. Rumah tipe ini sangat cocok untuk keluarga kecil dan masyarakat yang 
berdaya beli rendah. Rumah sederhana merupakan bagian dari program subsidi pemerintah untuk menyediakan hunian yang layak dan terjangkau bagi masyarakat berpenghasilan rendah. Pada umumnya rumah sederhana mempunyai luas rumah $22 \mathrm{~m}^{2} \mathrm{~s} / \mathrm{d} 36 \mathrm{~m}^{2}$, dengan luas tanah $60 \mathrm{~m}^{2} \mathrm{~s} / \mathrm{d}$ $75 \mathrm{~m}^{2}$.

b. Rumah Menengah

Rumah Menengah merupakan rumah bertipe sedang. Pada tipe ini, cukup banyak kebutuhan ruang yang dapat direncanakan dan perencanaan ruangnya lebih leluasa dibandingkan pada rumah

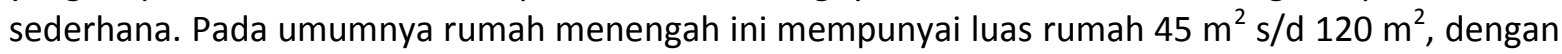
luas tanah $80 \mathrm{~m}^{2} \mathrm{~s} / \mathrm{d} 200 \mathrm{~m}^{2}$.

c. Rumah Mewah

Rumah Mewah merupakan rumah bertipe besar. Biasanya dimiliki oleh masyarakat berpenghasilan dan berdaya beli tinggi. Perencanaan ruang pada tipe ini lebih kompleks karena kebutuhan yang dapat direncanakan dalam rumah ini banyak disesuaikan dengan kebutuhan pemiliknya. Rumah tipe besar pada umumnya tidak hanya digunakan sebagai simbol status, simbol kepribadian, dan karakter pemilik rumah, ataupun simbol kebanggaan. Pada umumnya rumah mewah memiliki luas lebih dari $120 \mathrm{~m}^{2}$ dengan luasan tanah lebih dari $200 \mathrm{~m}^{2}$.

\subsection{Spasial Statistik \& Hot-Spot}

Spasial Statistik adalah alat analisis dalam Sistem Informasi Geografis yang berfungsi untuk menganalisis distribusi spasial, pola spasial, proses, dan hubungan spasial. Meskipun mungkin terdapat kesamaan antara spasial dan non-spasial (tradisional) statistik dalam hal konsep dan tujuan, spasial statistik lebih unik dikembangkan khususnya digunakan untuk data yang menyangkut geografis spasial. Spasial Statistik menggabungkan ruang yakni jarak, area, konektivitas dan hubungan spasial langsung menggunakan matematika (ESRI).

Analisis statistik juga digunakan untuk mengidentifikasi dan mengkonfirmasi bentuk pola spasial, seperti pemusatan kelompok, mengetahui tren arah, atau apakah terbentuk suatu klaster. Fungsi statistik yakni menganalisis data yang mendasari dan memberikan ukuran yang dapat digunakan untuk mengetahui keberadaan dan kekuatan pola. Dalam spasial statistic terdapat analisis klaster yang memperhitungkan tentang pola klaster yang terbentuk.

Hot Spot (Titik Panas) merupakan konsenstrasi dari kejadian dengan batas area geografis yang muncul dari waktu ke waktu. Hot Spot dapat digunakan pula untuk menilai konsentrasi spesifik dari guna lahan atau antara aktifitas dan guna lahan (Block \& C.R, 1995). Hot Spot mungkin tidak ada dalam kehidupan nyata, tetapi Hot Spot merepresentasikan dimana ada konsentrasi dari kegiatan atau kasus tertentu sehingga daerah tersebut dapat dicap sebagai daerah konsentrasi tinggi.

Terdapat puluhan teknik statistik analisis untuk mengidentifikasi Hot Spot (Everiit, 1974). Sebagian besar teknik analisis statistik digunakan yang biasa disebut dengan analisis klaster. Ini adalah teknik mengelompokkan kasus bersama-sama dalam kelompok yang relatif koheren. Semua tetap bergantung kepada bagaimana cara mengoptimalkan kriteria yang dipakai untuk diidentifikasi. Karena Hot Spot adalah sebuah konstruksi persepsi, teknik yang digunakan harus mendekati bagaimana seseorang memahami wilayah studi. Berikut adalah beberapa tipe metode Hot Spot/Cluster Anaysis (Everitt, 1974 dan Megbolougbe, 1996) :
1. Point Location
2. Hierarchical Techniques
3. Partitioning Techniques
4. Density Techniques
5. Clumping Techniques
6. Risk-based Techniques
7. Miscellanous Techniques

\subsection{Klaster dan Pola Spasial}

Menurut Tobler dalam bukunya "Hukum Pertama Geografi" mengungkapkan bahwa semua hal selalu berkaitan dengan semua hal lain, tetapi sesuatu yang lebih dekat lebih memiliki pengaruh daripada sesuatu yang jauh (Tobler, 1970). Distribusi spasial dengan nilai-nilai yang ada di lokasi 
tertentu menunjukan hubungan dengan lokasi lain disebut dengan autokorelasi spasial. Klaster spasial adalah autokorelasi spasial positif ketika ada nilai yang mirip mengelompok jadi satu, sedangkan kebalikannya jika terdapat nilai yang terpisah-pisah disebut dengan autokorelasi spasial negative (Boots et al., 1988). Dengan adanya klaster spasial dapat membantu pemahaman proses geografis yang mendasari hubungan dengan fenomena yang diteliti.

Berdasarkan klaster spasial yang telah ada maka akan terbentuk sebuah Pola Spasial (Spatial Pattern) yang berbeda-beda. Spatial Pattern atau Pola Spasial adalah sesuatu yang menunjukkan penempatan atau susunan benda-benda di permukaan bumi (Lee \& Wong, 2001). Pola spasial akan menjelaskan bagaimana fenomena geografis terdistribusi dan bagaimana perbandingannya dengan fenomena-fenomena lain. Pola spasial dapat berupa titik (Point) maupun luasan (Polygon), dan mereka dapat membentu pola yang bergerombol, tersebar, serta acak.

\section{METODOLOGI PENELITIAN}

Metode Analisis yang digunakan dalam penelitian ini menggunakan metode analisis Statistik Deskriptif. Dengan menggunakan metode statistic deskriptif, penyajian data dan analisis akan lebih mudah dipahami. Terdapat tiga tahap yang dilalui dalam penelitian ini yakni:

1. Tahap 1

a. Identifikasi karakteristik travel behavior masyarakat

b. Identifikasi karakteristik kepemilikan sepeda motor

2. Tahap 2

a. Analisis Hot Spot kepemilikan sepeda motor

b. Analisis Klaster dan Pola Spasial kepemilikan sepeda motor

3. Tahap 3

Identifikasi karakteristik distribusi spasial untuk mengetahui persebaran dan hubungan antara kepemilikan sepeda motor dan penggunaanya terhadap ruang yang ada.

\section{HASIL DAN PEMBAHASAN}

\subsection{Analisis Perilaku Perjalanan}

Pola pergerakan masyarakat pengguna sepeda motor di Kecamatan Banyumanik didasarkan terhadap perilaku perjalanan masyarakat. Setiap kelurahan di Kecamatan Banyumanik memiliki pola pergerakan yang berbeda-beda dan menunjukkan adanya hubungan antara pergerakan dengan guna lahan yang ada. Selain itu juga ditemukan kelurahan yang paling banyak terdapat komuter yang tinggal di Kecamatan Banyumanik. Berikut adalah gambar hasil pola pergerakan tiap kelurahan di Kecamatan Banyumanik.

Gambar 1. Pola pergerakan penggunaan sepeda motor di Kecamatan Banyumanik (Hasil Analisis Peneliti, 2014)

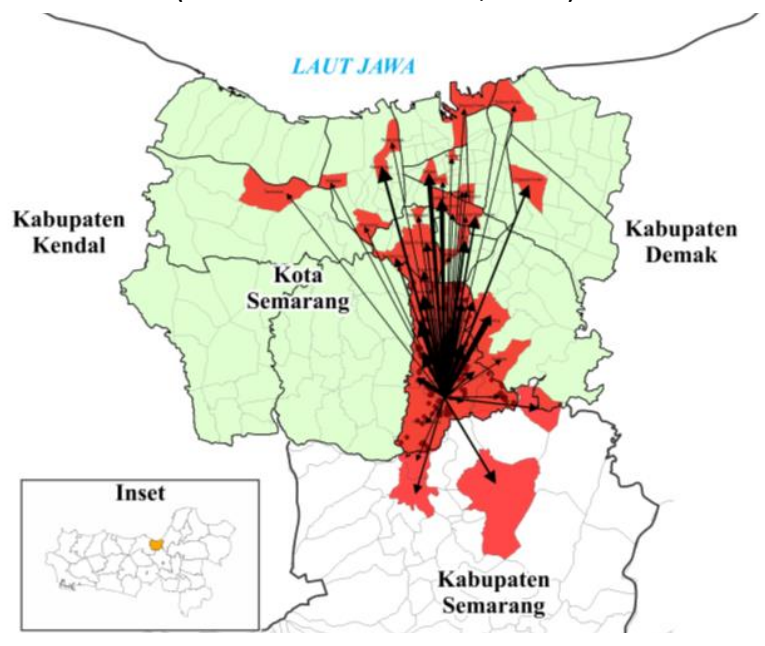


Gambar 2. Prosentase pergerakan masyarakat Kecamatan Banyumanik ke dalam dan luar Kota Semarang (Hasil Analisis Peneliti, 2014)

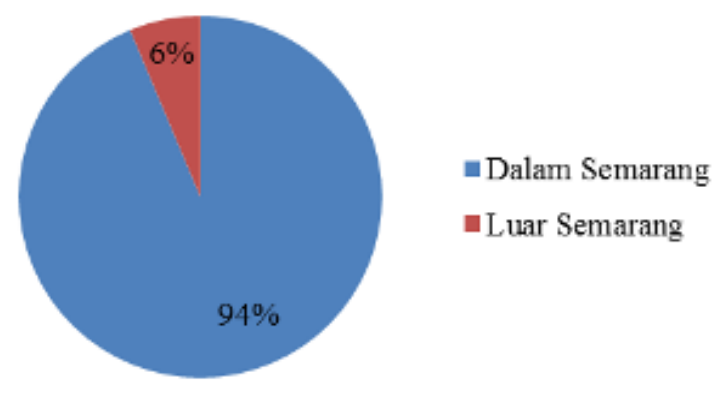

Gambar 3. Prosentase pergerakan masyarakat Kecamatan Banyumanik ke pinggiran, pusat dan luar kota (Hasil Analisis Peneliti, 2014)

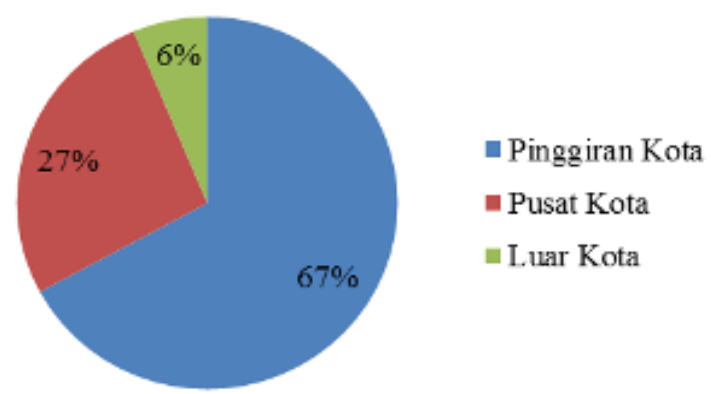

Berdasarkan gambar 1 menunjukkan bahwa anak panah menggambarkan tentang arah tujuan bekerja masyarakat Banyumanik, dan sumber panah digambarkan berada pada pusat Kecamatan Banyumanik. Ketebalan panah menunjukkan banyaknya arus pergerakan tujuan ke lokasi bekerja, semakin tebal panahnya maka akan semakin banyak masyarakat yang menuju lokasi tersebut.

Berdasarkan gambar 2 terlihat bahwa prosentasi masyarakat yang bekerja di Kecamatan Banyumanik yang bekerja di dalam Kota Semarang terbesar yakni mencapai 94\% sedangkan 6\% bekerja di wilayah Kabupaten Semarang yakni di Ungaran. Jika pembagian wilayah dalam dan luar Kota Semarang terbagi lagi menjadi tipologi kawasan maka akan terbentuk 3 kawasan baru yakni kawasan yang menuju ke pusat kota (27\%), kawasan pinggiran kota (67\%) dan kawasan yang berada di luar Kota Semarang (6\%).

\subsection{Analisis Kepemilikan Sepeda Motor}

Berdasarkan hasil survey maka didapatkan prosentasi hasil jumlah kepemilikan sepeda motor dalam rumah tangga sebagai berikut:

Gambar 4. Prosentase jumlah kepemilikan sepeda motor dalam rumah tangga

(Hasil Analisis Peneliti, 2014)

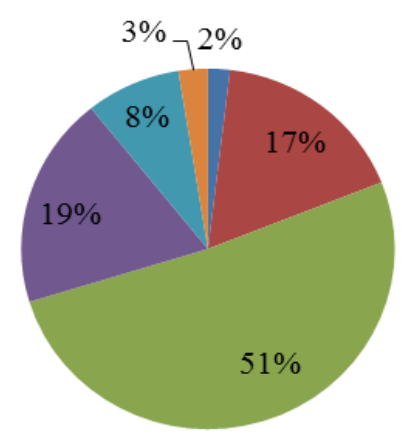

- 0 Sepeda Motor

- 1 Sepeda Motor

- 2 Sepeda Motor

- 3 Sepeda Motor

- 4 Sepeda Motor

- >4 Sepeda Motor 
Dari grafik diatas menunjukkan bahwa jumlah terbesar kepemilikan sepeda motor dalam 1 rumah tangga adalah sebanyak 2 buah sepeda motor dengan prosentase $51 \%$. Selanjutnya mencapai prosentase 19\% untuk kepemilikan 3 motor dan 17\% untuk kepemilikan berjumlah 1 motor. Namun terdapat masyarakat yang tidak memiliki sepeda motor dengan kemungkinan pertama bahwa masyarakat tidak mampu membeli sepeda motor dan lebih memilih jalan kaki atau masyarakat mampu membeli sepeda motor namun tidak membelinya. Dalam fakta dilapangan ditemukan bahwa sejumlah $2 \%$ masyarakat yang tidak memiliki sepeda motor adalah masyarakat yang bergolongan mampu namun tidak membeli sepeda motor. Hal ini dikarenakan sepeda motor dirasa kurang aman dalam berkendara dan kurang nyaman. Masyarakat yang tidak memiliki sepeda motor lebih cenderung berlokasi di kawasan perumahan atau perumahan mewah di Kecamatan Banyumanik seperti di Graha Estetika, Taman Setiabudi, Villa Aster dll.

\subsection{Analisis Hot Spot}

Analisis Hot Spot pada kepemilikan sepeda motor atribut yang digunakan adalah rasio antara jumlah sepeda motor yang dimiliki dengan jumlah anggota tiap keluarga dalam rumah tangga. Untuk menganalisis hot spot menggunakan tools analisis dalam Arc Map yang bernama "Hot Spot Analisys (Getis-Ord-Gi')". Selain atribut diatas dibutuhkan jarak maksimal tiap rumah tangga dalam 1 kecamatan, berdasarkan analisis sebelumnya hasilnya adalah 1.450 meter. Berdasarkan data yang telah diinput pada aplikasi Arc Map didapatkan hasil Hot Spot sebagai berikut.

Gambar 5. Peta Hot Spot (Titik Panas) Kepemilikan Sepeda Motor (Hasil Analisis Peneliti, 2014)

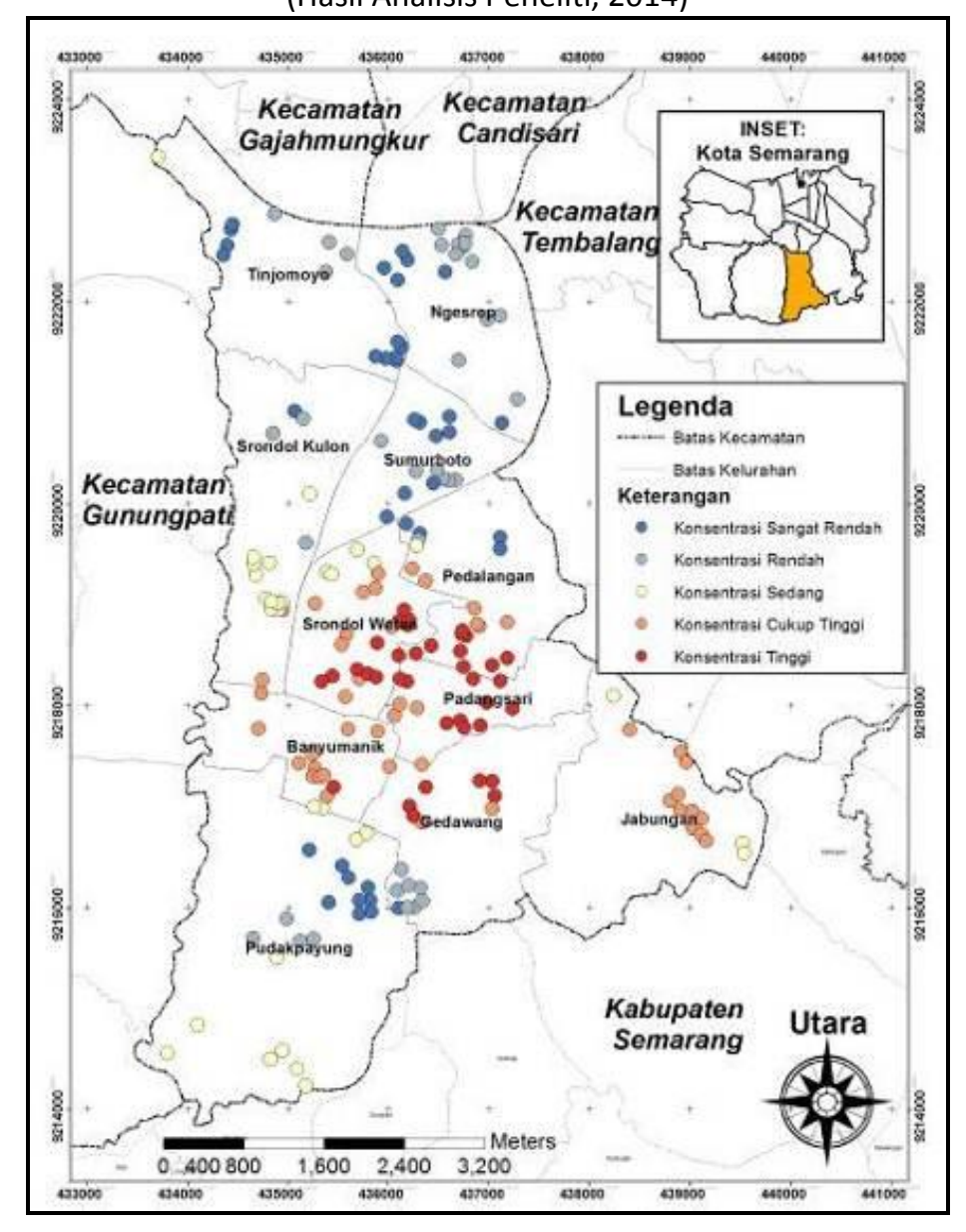

Berdasarkan gambar diatas titik panas menunjukkan bahwa dimana konsentrasi kepemilikan sepeda motor tiap rumah tangga terjadi. Terdapat 2 warna utama yakni merah dan biru, dimana warna merah menunjukkan konsentrasi kepemilikan sepeda motor per rumah tangga tinggi untuk warna biru sebaliknya semakin rendah. 


\subsection{Analisis Klaster dan Pola Spasial}

Pola Spasial kepemilikan sepeda motor ditunjukkan dengan peta konsentrasi jumlah kepemilikan sepeda motor di kawasan tertentu. Pola spasial yang terbentuk adalah berupa klaster. Berdasarkan hasil analisis didapatkan bahwa Perumnas Banyumanik memiliki kepemilikan sepeda motor yang paling besar, hal ini dikarenakan Perumnas Banyumanik merupakan kawasan permukiman padat dan bertipe rumah menengah. Untuk kepemilikan sepeda motor yang paling rendah berada pada kawasan perumahan mewah seperti Perumahan Graha Estetika dan Perumahan Bukitsari. Hal ini dikarenakan masyarakatnya yang cenderung lebih memilih menggunakan mobil daripada sepeda motor. Kemungkinan memiliki sepeda motor di kawasan ini ada, namun sangatlah kecil dengan rasio 0,2.

Gambar 6. Peta Klasifikasi Pola Spasial Kepemilikan Sepeda Motor (Hasil Analisis Peneliti, 2014)

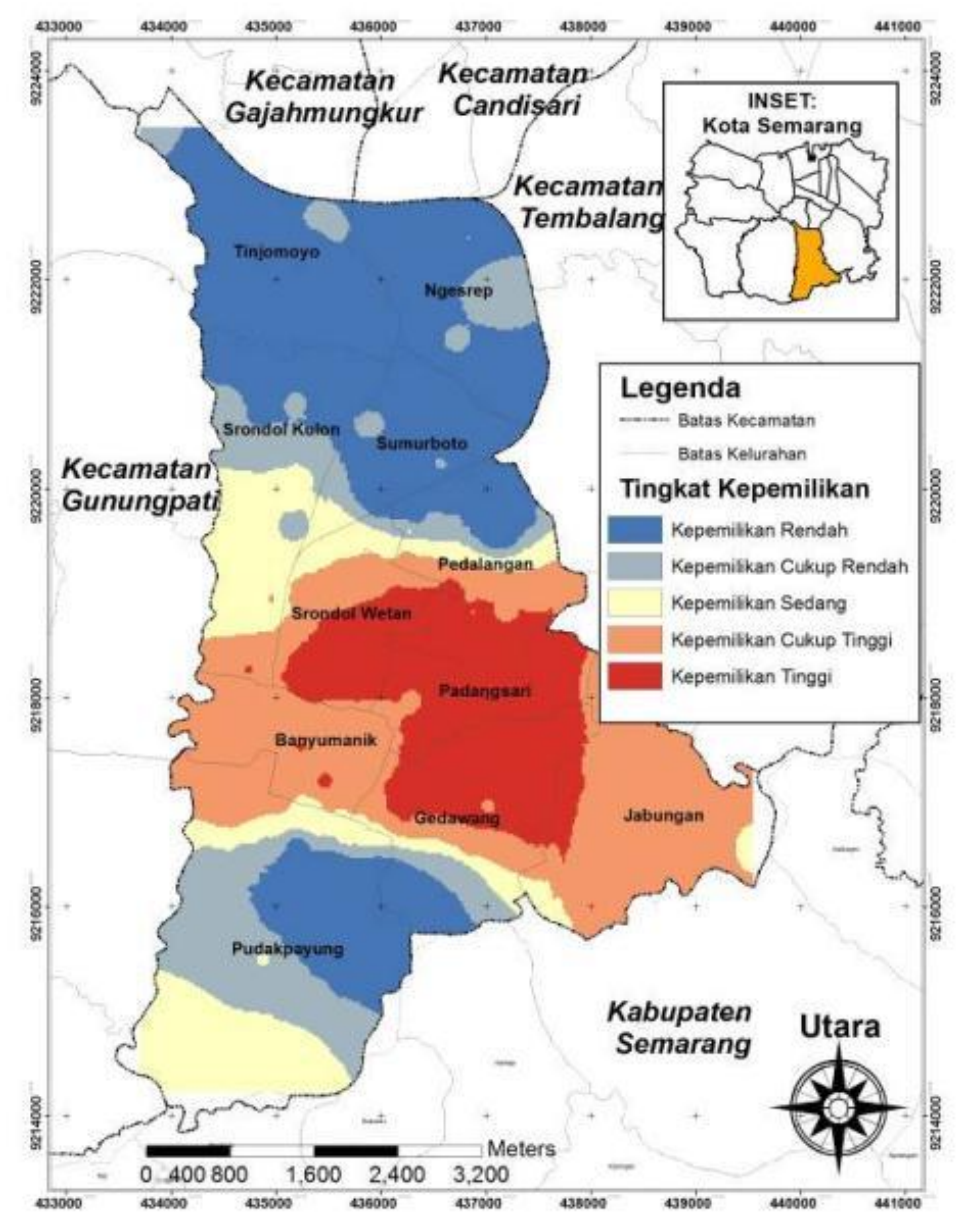

\subsection{Analisis Karakteristik Spasial}

Untuk mengidentikasi karakteristik spasial tentang kepemilikan sepeda motor dilakukan pembandingan tiap kelas klaster kepemilikan sepeda motor terhadap lokasi permukiman tempat masyarakat tinggal. Dengan melakukan pembandingan dan verifikasi kelas terhadap citra, maka akan didapatkan gambaran tentang bagaimana hubungan karakteristik spasialnya. Berikut adalah tabel identifikasi karakteristik spasial. 
Tabel 1. Identifikasi Karakteristik Spasial (Hasil Analisis Peneliti, 2014)

\begin{tabular}{|c|c|c|c|c|}
\hline Kelas & Citra & Kelas & Jenis Rumah & Lokasi \\
\hline pdol Wetan & hod Wetan & Kepemilikan Tinggi & $\begin{array}{l}\text { Rumah } \\
\text { Menengah }\end{array}$ & $\begin{array}{l}\text {-Perumnas } \\
\text { Banyumanik }\end{array}$ \\
\hline Banyuma & Banyuma & $\begin{array}{l}\text { Kepemilikan } \\
\text { Cukup Tinggi }\end{array}$ & $\begin{array}{c}\text { Rumah } \\
\text { Menengah }\end{array}$ & $\begin{array}{l}\text {-Kompleks } \\
\text { Rumpun } \\
\text { Diponegoro } \\
\text { - Kampung } \\
\text { Temugiring }\end{array}$ \\
\hline & & $\begin{array}{l}\text { Kepemilikan } \\
\text { Sedang }\end{array}$ & $\begin{array}{c}\text { Rumah } \\
\text { Menengah }\end{array}$ & $\begin{array}{l}\text { - Srondol Kulon } \\
\text { (Belakang ADA } \\
\text { Swalayan) }\end{array}$ \\
\hline & & $\begin{array}{l}\text { Kepemilikan } \\
\text { Sedang }\end{array}$ & $\begin{array}{l}\text { Rumah } \\
\text { Menengah }\end{array}$ & $\begin{array}{l}\text { - Pudak Payung } \\
\text { Asri }\end{array}$ \\
\hline & & $\begin{array}{l}\text { Kepemilikan } \\
\text { Cukup Rendah }\end{array}$ & $\begin{array}{c}\text { Rumah } \\
\text { Menengah }\end{array}$ & $\begin{array}{l}\text { - Kompleks Villa } \\
\text { Pudakpayung } \\
\text { - Kompleks } \\
\text { Pertamina } \\
\text { Pudakpayung }\end{array}$ \\
\hline & 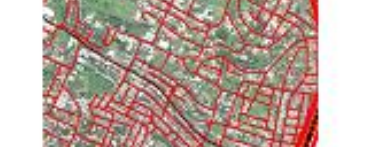 & $\begin{array}{l}\text { Kepemilikan } \\
\text { Rendah }\end{array}$ & $\begin{array}{l}\text { Rumah } \\
\text { Mewah }\end{array}$ & $\begin{array}{l}\text { - Kompleks } \\
\text { Perumahan } \\
\text { Bukitsari }\end{array}$ \\
\hline$P_{6}$ & Lis Pedalangan & $\begin{array}{l}\text { Kepemilikan } \\
\text { Rendah }\end{array}$ & $\begin{array}{l}\text { Rumah } \\
\text { Mewah }\end{array}$ & $\begin{array}{l}\text { - Kompleks } \\
\text { Perumahan } \\
\text { Graha } \\
\text { Estetika }\end{array}$ \\
\hline
\end{tabular}

Berdasarkan tabel diatas menunjukkan tentang lokasi dan status kelas kepemilikan sepeda motor di Kecamatan Banyumanik. Didapatkan hasil bahwa kepemilikan sepeda motor tertinggi terdapat pada kawasan Perumnas Banyumanik dan sekitarnya yang merupakan perumnas terbesar di Kecamatan Banyumanik. Kepemilikan sepeda motor cukup tinggi berada pada kawasan komplek Rumpun Diponegoro dan kampong Temugiring yang berada di sekitar komplek militer. Kepemilikan sepeda motor sedang terdapat di Kelurahan Srondolo Kulon yang berada di daerah belakang ADA Swalayan dan sekitarnya. Selain itu kepemilikan sepeda motor sedang juga terdapat di Pudak Payung Asri yang merupakan kawasan perumahan menengah. Untuk kepemilikan sepeda motor cukup rendah berada pada komplek Villa Pudak Payung dan Komplek Pertamina Pudak Payung yang juga merupakan perumahan menengah berada di pinggir jalan raya.

Sedangkan untuk status kepemilikan sepeda motor rendah berada pada kawasan perumahan Bukit Sari Ngesrep dan perumahan Graha Estetika yang mana merupakan kawasan perumahan mewah. 


\section{KESIMPULAN}

Jika dilihat secara keseluruhan Kecamatan Banyumanik, akan terdapat 37\% masyarakatnya yang bergerak menuju ke pusat Kota Semarang, 58\% masyarakatnya bergerak dan melakukan aktifitasnya di sekitar Kecamatan Banyumanik dan 5\% masyarakatnya bergerak keluar kota yakni ke Kabupaten Semarang. Pada tingkat kelurahan akan terdapat karakteristik pergerakan yang berbeda-beda pula.

Berdasarkan analisis pola spasial yang tebentuk dari kepemilikan sepeda motor, di dapatkan hasil bahwa terbentuk pola klaster. Jenis klaster yang terbentuk merupakan High Cluster (klaster tinggi), yang berarti distribusi dan konsentrasi kepemilikan sepeda motor tidak acak dan cenderung memusat. Klaster kepemilikan sepeda motor dikategorikan menjadi 5 kelas yakni kepemilikan tinggi, kepemilikan cukup tinggi, kepemilikan sedang, kepemilikan cukup rendah dan kepemilikan rendah. Berdasarkan hasil analisis dan pemetaan didapatkan hasil bahwa kepemilikan sepeda motor tertinggi berada pada kawasan Perumnas Banyumanik, hal ini dikarenakan Perumnas Banyumanik merupakan kawasan permukiman padat terbesar dan termasuk perumahan menengah. Untuk kepemilikan sepeda motor yang paling rendah berada pada kawasan perumahan mewah seperti Perumahan Graha Estetika dan Perumahan Bukitsari. Hal ini dikarenakan masyarakatnya yang cenderung lebih memilih menggunakan mobil daripada sepeda motor. Kemungkinan memiliki sepeda motor di kawasan ini ada, namun sangatlah kecil dengan rasio 0,2.

Untuk studi persebaran distribusi dan pola spasial kepemilikan sepeda motor di Kecamatan Banyumanik adalah membentuk sebuah klaster kepemilikan. Namun untuk berbagai kasus yang berada di kecamatan lain, perlu studi lebih lanjut untuk kaitan antara pola spasial dan pola distribusi atau pergerakan.

\section{DAFTAR PUSTAKA}

Block, R.L., and C.R. Block (1995). Space, place, and crime: Hot spot areas and hot places of liquor-related crime. In: J.E. Eck and D. Weisburd, eds., Crime and Place. Monsey, NY: Criminal Justice Press; and Washington, DC: Police Executive Research Forum, pp. 145-184.

BPS, 2013. Kota Semarang dalam Angka Tahun 2012. Kantor BPS Kota Semarang.

Boots, B.N., and Getis, A., (1988), Point Pattern Analysis. Newbury Park, CA: Sage Publications.

Everitt, B., (1974). Cluster Analysis. London: Heinemann Education Books.

Everitt \& Megbolugbe, I. (1996). The Geography of Underserved Mortgage Markets. Paper presented at the American Real Estate and Urban Economics Association meeting.

Lee, J. and Wong, D.W.S., (2001). Statistical Analysis with ArcView GIS. New York: John Wiley \& Sons Inc. Suparno, M., \& Marlina, E. (2006). Perencanaan dan Pengembangan Perumahan. Yogyakarta: Andi.

Tobler W., (1970) "A Computer Movie Simulating Urban Growth in the Detroit Region". Economic Geography, 46(2): 234-240.

Yudohusodo, S. 1991. Tumbuhnya Pemukim-Pemukim Liar di Kawasan Perkotaan. Jakarta : Yayasan Padamu Negeri. 